\title{
X-ray crystallographic and thermal studies on the hydrides of magnesium and its intermetallics
}

\author{
P SELVAM, B VISWANATHAN, C S SWAMY and V SRINIVASAN \\ Department of Chemistry, Indian Institute of Technology, Madras 600036 , India \\ MS received 11 August 1986; revised 12 December 1986
}

\begin{abstract}
Magnesium nickel hydride, $\mathrm{Mg}_{2} \mathrm{NiH}_{4}$, exists in two crystallographic modifications, the low temperature phase crystallizing in monoclinic structure and the high temperature phase having a cubic structure. The phase transition $(\sim 510 \mathrm{~K})$ was accompanied by a small composition change. The enthalpies and entropies of formation of these hydrides were calculated from the DTA data and compared with the values obtained by other methods.
\end{abstract}

Keywords. Magnesium nickel hydride; phase transition; enthalpy; entropy of formation.

\section{Introduction}

Among the magnesium alloys, $\mathrm{Mg}_{2} \mathrm{Ni}$ forms a ternary hydride, $\mathrm{Mg}_{2} \mathrm{NiH}_{4}$, with favourable hydrogen content (3.6 wt. \%), moderate stability and rapid kinetics (Reilly and Wiswall 1968). Its presence $\left(\mathrm{Mg}_{2} \mathrm{Ni}\right)$ also improves the hydriding kinetics of the binary hydride, $\mathrm{MgH}_{2}$ (Reilly and Wiswall 1968; Seiler et al 1980). The earliest crystallographic and thermal studies of $\mathrm{Mg}_{2} \mathrm{NiH}_{4}$ by Gavra et al (1979) showed a reversible allotropic phase transition around $485-520 \mathrm{~K}$. There are various reports of crystallographic studies and thermal analyses on this system with a view to elucidate the crystal symmetry of the hydride as well as to identify the phase transformation (Reilly and Wiswall 1968; Gavra et al 1979; Mintz et al 1980; Schefer et al 1980; Hirata et al 1981; Darnaudery et al 1981; Andresen et al 1981; Schefer et al 1981; Noreus and Werner 1981, 1984; Genossar and Rudman 1981; Yvon et al 1981; Ono et al 1982a,b; Darnaudery et al 1983a; Noreus and Olsson 1983; Hayakawa et al 1984; Soubeyroux et al 1984a,b; Carter and Carter 1984; Gavra et al 1985; Zolliker et al 1986).

There has been a great interest in the thermodynamic properties of metal hydrides because of their importance in various technical purposes as well as in the physical understanding of metal-hydrogen reactions. Numerous experimental (Mueller et al 1968; Andresen and Maeland 1978; Alefeld and Volkl 1978; Bambakidis 1981; Wenzl and Labsanft 1983) and theoretical (Switendick 1972; Van Mal et al 1974; Lundin et al 1977; Gelatt et al 1978; Bouten and Miedema 1980) investigations on the thermodynamic aspects of the interaction of hydrogen with metals, alloys and intermetallic compounds have been reported. Experimentally the thermodynamic quantities can be obtained from pressure-composition isotherms (p-c-T) (Buchner 1978; Fischer et al 1978; Sandrock and Huston 1981) or from related equivalent approach of electrode potential-composition-temperature relationships or from heat capacity measurements (Flanagan and Oates 1972) or from calorimetric methods (Reilly and Wiswall 1974; Labsanft 1979; Bowerman et al 1979, 1980; Murray et al 1981, 1983; Pasturel et al 1982; Wenzl and Labsanft 1983). Recently Shilov et al (1983) suggested 
an alternative method based on approximate enthalpy balance equation in conjunction with differential thermal analysis (DTA).

The present investigation was undertaken to obtain information on the conflicting reports on $x$-ray crystallographic data for the structural modifications of $\mathrm{Mg}_{2} \mathrm{NiH}_{4}$ and the thermodynamic characteristics of the magnesium and its alloy hydrides using the DTA technique.

\section{Starting materials}

The sources of the samples used in the present study are BDH-GLAXO Laboratories Ltd., (India) (36 mesh, 99.5\% purity) or/and SISCO Research Laboratories Pvt. Ltd. (India) (36 mesh, 99.8\% purity) for magnesium, (Koch-Light Laboratories Ltd., U.K.; for nickel (100 mesh, 99.8\% purity)) and SISCO Research Laboratories Pvt. Ltd. (India) for Copper (200 mesh, 99.5\% purity). Commercial samples of $\mathrm{Mg}_{2} \mathrm{Ni}$ and $\mathrm{Mg}_{2} \mathrm{Cu}$ alloys used in the present study were supplied by the Ergenics Division of the MPD Technology Corporation, New Jersey (USA) with the designation Hystor-301 and 302 respectively. High purity argon (Iolar-1 grade) and hydrogen (Iolar-1 grade) supplied by $\mathrm{M} / \mathrm{s}$ Indian Oxygen Limited with a maximum oxygen content of $2 \mathrm{ppm}$ were used for the preparation and hydriding purposes respectively.

\section{Experimental procedures}

\subsection{Preparation of alloys and hydrides}

The alloys $\mathrm{Mg}_{2} \mathrm{Ni}$ and $\mathrm{Mg}_{2} \mathrm{Cu}$ were prepared by heating pure metals in the stoichiometric ratio at $1125 \mathrm{~K}$ and annealing it in argon for $48 \mathrm{hr}$ at $825 \mathrm{~K}$. The hydrides were synthesized in an autoclave with a maximum operating temperature of $673 \mathrm{~K}$ and a pressure of $150 \mathrm{~atm}$.

\subsection{X-ray diffraction and thermal analysis}

X-ray powder diffraction measurements were carried out with or without a heating stage facility on a diffractometer (Philips model $\mathrm{PW}-1140$ ) using $\mathrm{CuK}_{\alpha}$ radiation. Simultaneous differential thermal and thermogravimetric analyses (DTA-TGA) were performed under $1 \mathrm{~atm}$ hydrogen/argon pressure using a thermogravimetric and differential thermal analysis combined unit (Stanton Redcroft thermal analyzer, model STA-780) upto $725 \mathrm{~K}$ with a heating rate of $10 \mathrm{~K}$ per min.

\section{Results and discussion}

\subsection{X-ray diffraction analysis}

The hydride, $\mathrm{Mg}_{2} \mathrm{NiH}_{4}$ was found to have a different crystallographic form at higher temperatures $(510 \mathrm{~K})$. This suggests a structural phase transition (Stucki 1983). The X-ray diffraction data of the LT-phase (room temperature) of $\mathrm{Mg}_{2} \mathrm{NiH}_{4}$ could be 
indexed on the basis of a monoclinic unit cell while the HT-phase (above $510 \mathrm{~K}$ ) could be indexed on the basis of a cubic symmetry. Therefore, the $\mathrm{Mg}_{2} \mathrm{NiH}_{4}$ sample was found to undergo a structural phase transition from a LT-monoclinic to a HTcubic phase around $510 \mathrm{~K}$. The values of the least square refined cell parameters for the LT- and HT-phases obtained in the present study are given in table 1. The $\mathrm{x}$-ray diffraction data obtained in the present study favour a monoclinic structure for the LT-phase and a cubic structure for the HT-phase.

Thus, the preparation conditions employed in the present study favour mainly a monoclinic structure which has a distorted cubic symmetry. The $\mathrm{x}$-ray densities of the LT- and HT-forms of the samples 2.71 and $2.67 \mathrm{gm} / \mathrm{cm}^{3}$ respectively are in reasonable agreement with the experimental values reported (Reilly and Wiswall 1968; Mintz et al 1980; Ishido et al 1982; Post et al 1984) and agree well with the calculated values (Genossar and Rudman 1981; Ono et al 1984).

\subsection{Differential thermal and thermogravimetric analyses}

DTA thermograms were obtained for the hydrides of $\mathrm{Mg}, \mathrm{Mg}_{2} \mathrm{Ni}$ and $\mathrm{Mg}_{2} \mathrm{Cu}$ samples by heating them in the temperature range from room temperature to $725 \mathrm{~K}$ under hydrogen/argon atmospheres. The decomposition of the hydrides is seen by the endothermic peaks (see table 2 for the decomposition temperatures). It is seen that the hydrides decompose at lower temperatures for the intermetallic hydrides compared to the binary system $\mathrm{MgH}_{2}$.

The decomposition temperatures in argon atmosphere are lower than those observed in the hydrogen atmosphere (refer to data given in table 2) and these values agree with the reported decomposition temperatures from pressure-composition isotherms. Hirata et al (1984) observed that the decomposition temperature of the hydride of $\mathrm{Mg}_{2} \mathrm{Ni}$ can be as high as $598 \mathrm{~K}$ in $0.1 \mathrm{MPa}$ of hydrogen pressure. Gavra et al (1979) reported that the decomposition temperature of $\mathrm{Mg}_{2} \mathrm{NiH}_{4}$ under 700 torr of hydrogen pressure is around $553-573 \mathrm{~K}$. The results of the present study agree with these reports.

The thermal analysis of $\mathrm{Mg}_{2} \mathrm{NiH}_{4}$ carried out in $1 \mathrm{~atm}$ hydrogen pressure showed two endothermic peaks revealing a reversible phase transition and decomposition around $510 \mathrm{~K}$ and $555 \mathrm{~K}$ respectively (figure 1). The smali endothermic peak around

Table 1. X-ray data for the LT- and HT-forms of $\mathrm{Mg}_{2} \mathrm{NiH}_{+}$samples.

\begin{tabular}{|c|c|c|}
\hline \multirow[b]{2}{*}{$\begin{array}{l}\text { Source } \\
\left(\mathrm{Mg}_{2} \mathrm{NiH}_{4} \text { sample }\right)\end{array}$} & \multicolumn{2}{|c|}{ Structure and cell parameters } \\
\hline & $\begin{array}{c}\text { LT form } \\
\text { (monoclinic) }\end{array}$ & $\begin{array}{l}\text { HT form } \\
\text { (cubic) }\end{array}$ \\
\hline & $\begin{array}{l}a=6.581 \mathrm{~A}^{\circ} \\
b=6.400 \mathrm{~A}^{\circ}\end{array}$ & \\
\hline Synthesized & $\begin{array}{l}c=6.499 \mathrm{~A}^{\circ} \\
\beta=93 \cdot 10^{\circ}\end{array}$ & $a=6.519 \mathrm{~A}^{\circ}$ \\
\hline & $a=6.585 \mathrm{~A}^{n}$ & \\
\hline Hystor-301 & $\begin{array}{l}b=6.406 \mathrm{~A}^{c} \\
r=6.493 \mathrm{~A}^{\circ} \\
\beta=93.10^{\circ}\end{array}$ & $a=6.521 \mathrm{~A}^{\circ}$ \\
\hline
\end{tabular}




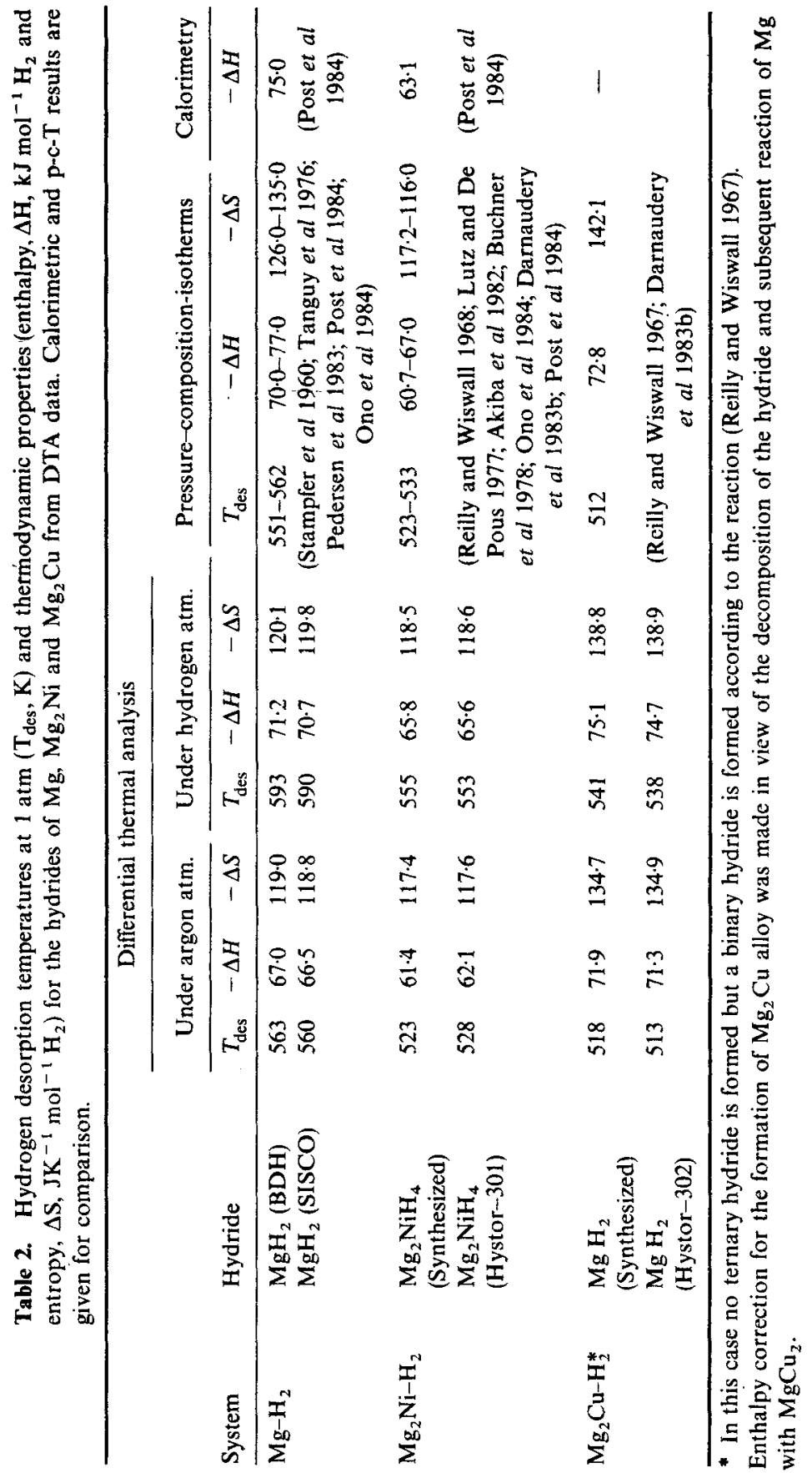




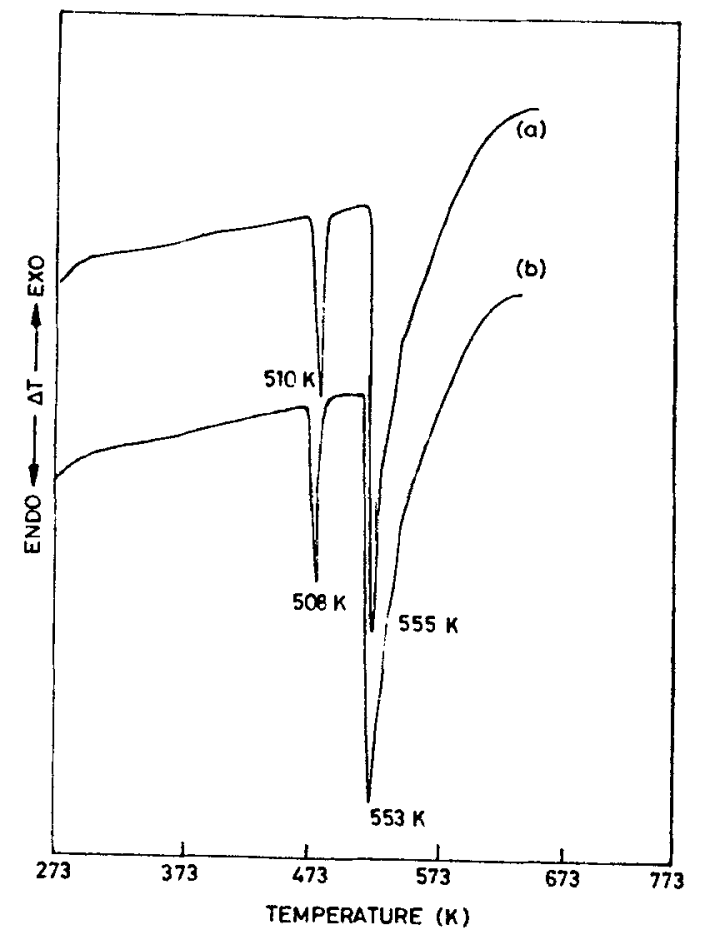

Figure 1. DTA curves for the dehydriding behaviour of $\mathrm{Mg}_{2} \mathrm{NiH}_{4}$ under hydrogen atmosphere: (a) Synthesized. (b) Hystor-301.

$510 \mathrm{~K}$ could be attributed to the structural transition from LT-hydride form to HTform (Gavra et al 1979; Hirata 1984; Noreus and Werner 1984) and is associated with a small change in the composition as observed from TGA studies. This allotropic transition appeared reversibly during repeated heating-cooling cycles. The heat change involved in the transition was calculated as $3.3 \mathrm{KJ} \mathrm{mol}^{-1} \mathrm{H}_{2}$ by Gavra et al (1979) employing a differential scanning calorimetry (DSC) technique. However, only one broad endotherm is observed during the decomposition of $\mathrm{Mg}_{2} \mathrm{NiH}_{4}$ in argon atmosphere. The endotherm starts at the phase transition temperature. Therefore, it is assumed that the broad endotherm is due to both the phase transition and decomposition of the hydrides. The endotherm is not separated even at a lower heating rate of $5 \mathrm{~K}$ per min.

TGA studies suggest that the desorbed hydrogen in $\mathrm{Mg}, \mathrm{Mg}_{2} \mathrm{Ni}$ and $\mathrm{Mg}_{2} \mathrm{Cu}$ hydrides corresponds to the stoichimetry of the hydride formed. In addition, a small weight loss is observed in the case of $\mathrm{Mg}_{2} \mathrm{NiH}_{4}$ in the phase transition region suggesting a different composition of the polymorphic varieties, i.e. the LT-monoclinic phase being the stoichiometric phase $\left(\mathrm{Mg}_{2} \mathrm{NiH}_{4}\right)$ and the HT-cubic phase being the sub-stoichiometric phase $\left(\mathrm{Mg}_{2} \mathrm{NiH}_{4-x}\right)$.

Based on the method of Shilov et al (1983), the enthalpies and entropies of formation of the magnesium and its intermetallic hydrides were calculated from the DTA data. The calculated thermodynamic quantities along with the desorption temperatures are given in table 2 . The results are comparable with the data deduced from p-c- $\mathrm{T}$ relationships and calorimetric measurements. However, the values cal- 
culated from DSC measurements by Gavra et al (1979), Ono et al (1982b) and Hirata (1984) are $47 \cdot 3,59 \cdot 0$ and $58.9 \mathrm{KJ} \mathrm{mol}^{-1} \mathrm{H}_{2}$ respectively. They are somewhat lower than the values calculated from the DTA studies or from the conventional $\mathrm{p}-\mathrm{c}-\mathrm{T}$ relationships and calorimetric measurements.

\section{Acknowledgement}

Thanks are due to the Department of Non-Conventional Energy Sources (DNES), Ministry of Energy, Government of India, New Delhi for the award of a research grant.

\section{References}

Akiba E, Nomura K, Ono S and Suda S 1982 Int. J. Hydrogen Energy 7787

Alefeld G and Volkl J 1978 Hydrogen in metals II-Topics in applied physics (Berlin: Springer-Verlag) vol. 29 Andresen A F, Andersen E and Pattersen K 1981 Acta Crystallogr. Suppl. C A37 152

Andresen A F and Maeland A J 1978 Hydrides for energy storage-Proc. Int. Symp. (Oxford: Pergamon Press)

Bambakidis G 1981 Metal hydrides-NATO advanced study Institutes Series B: Physics (New York: Plenum Press) vol. 76

Bouten P C P and Miedema A R 1980 J. Less-Common Metals 71147

Bowerman B S, Wulff C A, Biehl G E and Flanagan T B 1980 J. Less-Common Metals 731

Bowerman B S, Wulff C A and Flanagan T B 1979 Z. Phys. Chem. N.F. 116197

Buchner H 1978 Int. J. Hydrogen Energy 3385

Buchner H, Bernauer O and Streub W 1978 in Proc. Second World Hydrogen Energy Conf. on Hydrogen Energy Systems (eds) T N Veziroglu and W Seifritz (New York: Pergamon Press) vol. 3, p. 1677

Carter G C and Carter F L 1984 in Metal hydrogen systems (ed) T N Veziroglu (New York: Pergamon Press)

Darnaudery J P, Pezat M, Darriet B and Hagenmuller P 1981 Mater. Res. Bull. 161237

Darnaudery J P, Pezat M and Darriet B 1983a J. Less-Common Metals 92199

Darnaudery J P, Darriet B and Pezat M 1983b Int. J. Hydrogen Energy 8705

Fischer P, Halg W, Schlapbach L, Stucki F and Andresen A F 1978 Mater. Res. Bull. 13931

Flanagan T B and Oates W A 1972 Ber. Bunsenges. Phys. Chem. 76706

Gavra Z, Kimmel G, Gefen Y and Mintz M H 1985 J. Appl. Phys. 574548

Gavra Z, Mintz M H, Kimmel G and Hadari Z 1979 Inorg. Chem. 183595

Gelatt C D, Ehrenreich M and Weise J A 1978 Phys. Rev. B17 1970

Genossar J and Rudman P S 1981 J. Phys. Chem. Solids 42199

Hayakawa H. Ishido Y, Nomura K, Uruno H and Ono S 1984 J. Less-Common Metals 103277

Hirata T 1984 Int. J. Hydrogen Energy 9255

Hirata T, Matsumoto T, Amano M and Sasaki Y 1981 J. Phys. F11 521

Ishido Y, Kawamura M and Ono S 1982 Int. J. Hydrogen Energy 7173

Lebsanft E 1979 J. Phys. E12 699

Lundin C E, Lynch F E and Magee C B 1977 J. Less-Common Metals 5619

Lutz H M and De Pous 1977 in Proc. Second Int. Cong. on Hydrogen in Metals (Paris: Pergamon Press) vol. 1, p. $1 \mathrm{~F} 5$

Mintz M H, Gavra Z, Kimmel G and Hadari Z 1980 J. Less-Common Metals 74263

Mueller W M, Blackledge J P and Libowitz G G 1968 Metal hydrides (New York: Academic Press)

Murray J J, Post M L and Taylor J B 1981 J. Less-Common Metals 80201

Murray J J, Post M L and Taylor J B 1983 J. Less-Common Metals 9065

Noreus D and Olsson L G 1983 J. Chem. Phys. 782419

Noreus D and Werner P E 1981 Mater. Res. Bull. 16199

Noreus D and Werner P E 1984 J. Less-Common Metals 97215

Ono S, Hayakawa M, Suzuki A, Nomura K, Nishimiya N and Tabata T 1982b J.Less-Common Metals 88 63 
Ono S, Ishido Y, Imanari T, Tabata T, Cho Y K, Yamamoto R and Doyama M 1982a J.Less-Common Metals 8857

Ono S, Ishido Y, Akiba E, Jindo K, Saweda Y, Kitagawa I and Kakutani T 1984 in Hydrogen energy progress V-Proc. 5th world Hydrogen energy conf. (ed) T N Veziroglu (Toronto: Pergamon Press) p. 1291

Pasturel A, Colinet C C, Guegan A P and Achard J L 1982 J. Less-Common Metals 8473

Pedersen A S, Kjoller B, Larsen B and Vigeholm B 1983 Int. J. Hydrogen Energy 8205

Post M L, Murray J J and Taylor J B 1984 Int. J. Hydrogen Energy 9137

Reilly J J and Wiswall R H 1967 Inorg. Chem. 62220

Reilly J J and Wiswall R H 1968 Inorg. Chem. 72254

Reilly J J and Wiswall R H 1974 Inorg. Chem. 13218

Sandrock G D and Huston E L 1981 Chem. Tech. 11754

Schefer J, Fischer P, Halg W, Stucki F, Schlapbach L, Didisheim J J, Yvon K and Andresen A F 1980 J. Less-Common Metals 7465

Schefer J, Fischer P, Stucki F, Schlapbach L, Baerelocher Ch, Yvon K, Didisheim J J, Jorgensen J D and Andresen A F 1981 in Prog. Rep. AF-SSP-118 (Zurich: Institut fur Reaktortechnik Eidgenossische Technische Hochschule) p. 52

Seiler A, Schlapbach L, von Waldkirch Th, Shaltiel D and Stucki F 1980 J. Less-Common Metals 73193

Shilov A L, Padurets L N and Kost M E 1983 Russ. J. Inorg. Chem. 57338

Soubeyroux J L, Fruchart D, Mikou A, Pezat M, Darriet B and Hagenmuller P 1984a Mater. Res. Bull. 19969

Soubeyroux J L, Fruchart D, Mikou A, Pezat M and Darriet B 19.84b Mater. Res. Bull. 191119

Stampfer J F, Holley C E and Suttle J F 1960 J. Am. Chem. Soc. 823504

Stucki F 1983 Int. J. Hydrogen Energy 849

Switendick A.C 1972 Solid State Commun. 81463

Tanguy B, Soubeyroux J L, Pezat M, Portier J and Hagenmuller P 1976 Mater. Res. Bull. 111441.

Van Mal H H, Buschow K H J and Miedema A R 1974 J. Less-Common Metals 3565

Wenzl H and Lebsanft E 1983 J. Phys. F10 2147

Yvon K, Schefer J and Stucki F 1981 Inorg. Chem. 202776

Zolliker P, Yvon K and Beerlocher Ch 1986 J. Less-Common Metals 11565 